\title{
EPIDEMIC DROPSY OUTBREAK IN LOCALIZED COMMUNITY OF HARYANA, INDIA
}

\author{
SONIKA LAMBA ${ }^{\mathrm{a}}$, RUPAN DEEP KAUR ${ }^{\mathrm{b}}$, MANOJ RAWAL ${ }^{\mathrm{c} 1}$ AND UPENDRA PUJARI ${ }^{\mathrm{d}}$

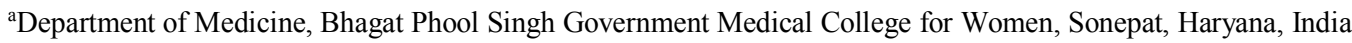 \\ bJunior Resient, Bhagat Phool Singh Government Medical College for Women, Sonepat, Haryana, India \\ 'Department of Paediatrics, Bhagat Phool Singh Government Medical College for Women, Sonepat, Haryana, India

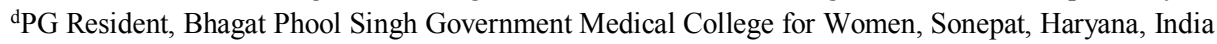

\begin{abstract}
The outbreak of epidemic dropsy in the Indian capital, New Delhi, during the rainy season of 1998 was of one of the most severe forms and had repercussions in both health and political circles. Some 2552 cases were reported and 65 deaths occurred between 5 August and 12 October, causing untold misery and economic loss to the affected families. The actual figures are likely to be much higher due to non-reporting of milder cases to the hospitals. The aim of this article is to consolidate and update the available information on clinical aspects of epidemic dropsy.
\end{abstract}

KEYWORDS: Epidemic, Argemone oil

Epidemic dropsy results from the accidental ingestion of mustard oil adulterated with oil extracted from the seeds of Argemone Mexicana (Sarkar, 1926). The main alkaloid of Argemone oil is toxic, and belongs to the class of benzophenanthridine group, namely sanguinarine and dihydro-sanguinarine. Lyon reported the first four cases of argemone oil poisoning from Bombay in 1877 (Das and Khanna, 1997) (Sachdev et al., 1989). Various epidemics have been reported, in India from Calcutta (1877), Assam, Bihar, Eastern U.P, Orissa, Madhya Pradesh, Gujrat and Delhi since then (Das and Khanna, 1997) (Smith, 1937). Epidemic Dropsy is an acute non-infectious disease characterized by pitting edema of the extremities, especially of the lower limbs; cutaneous erythema; and local tenderness (Singh et al., 1999) (Kumar et al., 1992). Glaucoma and other visual field defects, leading to blindness, and cardiac and respiratory problems, leading to death are among the most severe manifestations of the condition (Rathore, 1982) (Singh et al., 2006) (Gupta, 2009) (Park, 2009) (Das and Khanna, 1998).

\section{MATERIALS AND METHODS}

All members of the concerned family were interviewed and those requiring medical attention were hospitalized. A survey of the surrounding area was conducted to identify similar cases in the vicinity, if any. A thorough personal and medical history, history of present illness, and clinical features of each patient was noted. Blood was collected for hemoglobin, total leukocyte, and differential leukocyte counts and urine samples were collected for urine examination. Written informed consent before data collection was obtained from all the study participants.

Mustard oil samples were collected from the affected family, six neighboring households, and from the shop where the family got mustard oil extraction done. The oil samples were tested for contamination of argemone oil using the Nitric acid test, Cupric Acid test and Ferric chloride test.

1. Nitric Acid Test: Took $5 \mathrm{ml}$ of adultered mustard oil in a test tube. To this we added $5 \mathrm{ml}$ of concentrated nitric acid and the test tube was shaken. Orange yellow colour was developed in the acid layer confirming the presence of argemone oil in the sample.

2. Cupric Acid Test: Took $5 \mathrm{ml}$ of adulterated oil in a test tube. To this $1 \mathrm{ml}$ of glacial acetic acid and $2 \mathrm{mg}$ of cupric acetate solution was added. Green colour confirmed the presence of argemone oil in the sample.

3. Ferric Chloride test: Took $5 \mathrm{ml}$ of adulterated oil sample in a test tube. To this we added $2 \mathrm{ml}$ of concenterated $\mathrm{HCl}$ of rectified spirit. It was shaken for 1 minute. The acid and oil layers were cleared separately. 


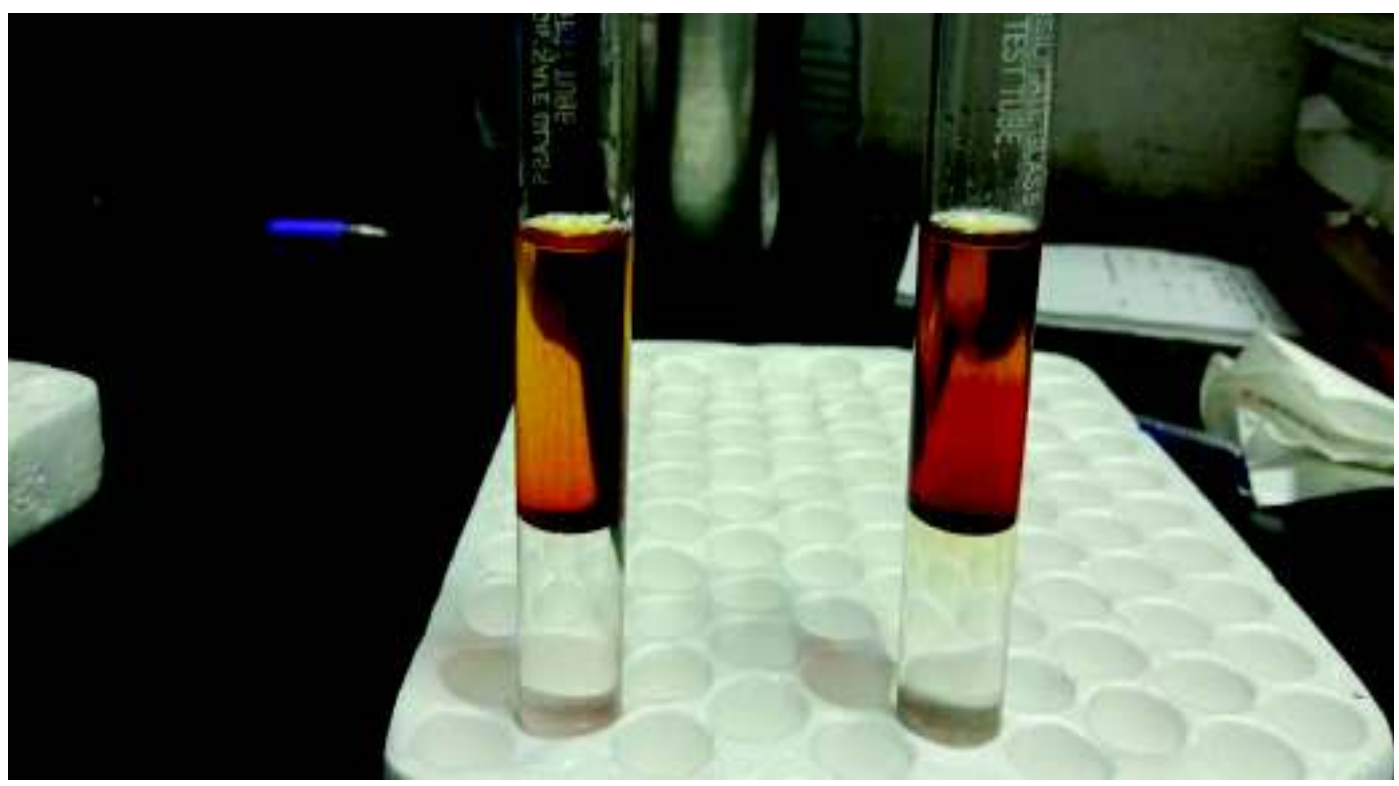

Figure 1: Orange yellow colour was developed in the acid layer confirming the presence of argemone oil in the sample

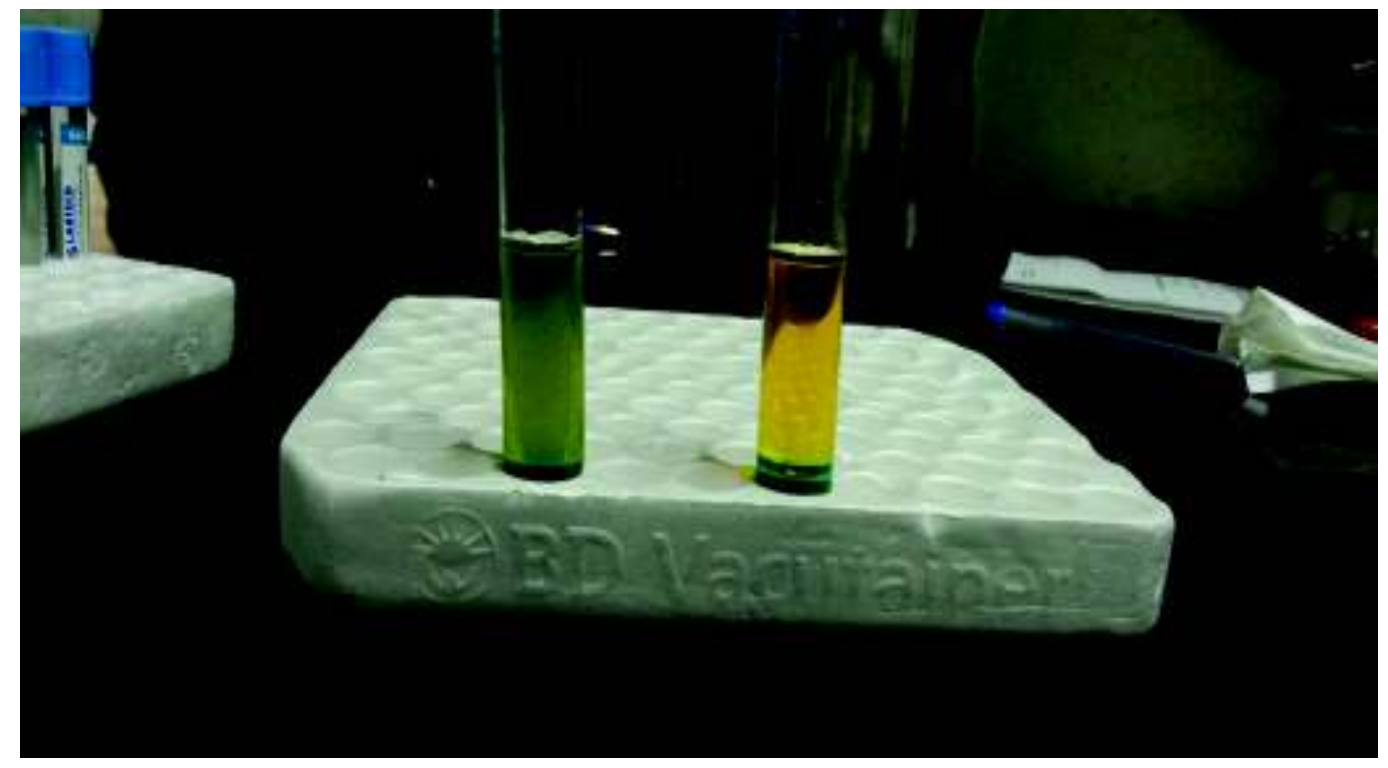

Figure 2: Green colour confirmed the presence of argemone oil in the sample

\section{CASE REPORT}

A 41-year old man presented to the emergency services with a month history of a burning sensation, swelling and redness over the feet. He also complained of a recent-onset diarrhea which was not associated with fever, tenesmus, abdominal pain, distension or vomiting.

The patient was cooperative and well oriented to time, place and person. Vital signs were abnormal, with the pulse rate at 118 beats per minute and respiratory rate at 26 breaths per minute, and a blood pressure of 141/98 $\mathrm{mmHg}$. The patient had no jaundice, cyanosis, clubbing or lymphadenopathy was detected. Examination of the lower limbs revealed pitting edema up to the lower abdominal wall, and tenderness in the same distribution. Abdominal and neurological examinations were normal and on auscultation of chest normal $S_{1}$ and $S_{2}$ were heard with no added sounds. The results of his laboratory investigations are summarized in the table. 
LAMBA ET AL.: EPIDEMIC DROPSY OUTBREAK IN LOCALIZED COMMUNITY OF HARYANA, INDIA

Table 1: Results of laboratory investigations of the index case

\begin{tabular}{|c|c|c|c|}
\hline Investigation & Results & Units & Bio. Ref. Level \\
\hline Hemoglobin & 12.90 & $\mathrm{~g} / \mathrm{dl}$ & $13.00-17.00$ \\
\hline Total leukocyte count & 8.00 & Thou $/ \mathrm{mm}^{3}$ & $4.00-10.00$ \\
\hline Platelet count & 264.0 & Thou $/ \mathrm{mm}^{3}$ & $150.00-450.00$ \\
\hline $\mathrm{MCV}$ & 71.00 & $\mathrm{fL}$ & $80.00-100.00$ \\
\hline $\mathrm{MCH}$ & 22.40 & $\mathrm{Pg}$ & $27.00-32.00$ \\
\hline $\mathrm{MCHC}$ & 31.60 & $\mathrm{~g} / \mathrm{dl}$ & $32.00-35.00$ \\
\hline $\begin{array}{c}\text { Red Cell Distribution } \\
\text { Width }\end{array}$ & 14.80 & $\%$ & $11.50-14.50$ \\
\hline $\mathrm{HbA1c}$ & 5.4 & $4.0-5.6$ & $\%$ \\
\hline Blood sugar & 74.0 & $\mathrm{mg} / \mathrm{dl}$ & Up to $160 \mathrm{mg} / \mathrm{dl}$ \\
\hline Blood urea & 25.0 & $\mathrm{mg} / \mathrm{dl}$ & $15-45$ \\
\hline Serum creatinine & 0.55 & $\mathrm{mg} / \mathrm{dl}$ & $\begin{array}{c}0.4-1.3 \text { (male) } \\
0.4-1.2 \text { (female) }\end{array}$ \\
\hline Total Cholesterol & 192.00 & $\mathrm{mg} / \mathrm{dl}$ & $<200.00$ \\
\hline Triglycerides & 143.00 & $\mathrm{mg} / \mathrm{dl}$ & $<150.00$ \\
\hline HDL Cholesterol & 44.00 & $\mathrm{mg} / \mathrm{dl}$ & $>40.00$ \\
\hline LDL Cholesterol & 119.40 & $\mathrm{mg} / \mathrm{dl}$ & $<100.00$ \\
\hline VLDL Cholesterol & 28.60 & $\mathrm{mg} / \mathrm{dl}$ & $<130$ \\
\hline $\mathrm{T}_{3}$ Total & 0.82 & $\mathrm{ng} / \mathrm{ml}$ & $0.70-2.04$ \\
\hline $\mathrm{T}_{4}$ Total & 8.58 & $\mathrm{ug} / \mathrm{dl}$ & $5.74-13.03$ \\
\hline TSH & 1.70 & $\mathrm{uIU} / \mathrm{ml}$ & $0.34-5.60$ \\
\hline 24 hour Urine Protein & 262.00 & $\mathrm{mg} / 24 \mathrm{hr}$ & $<140$ \\
\hline Albumin & 1.7 & $\mathrm{~g} / \mathrm{dl}$ & $6.40-8.30$ \\
\hline A:G ratio & 4.50 & $\mathrm{~g} / \mathrm{dl}$ & $3.50-5.20$ \\
\hline Total Protein & 6.5 & & $0.90-2.00$ \\
\hline AST & 20 & $\mathrm{U} / \mathrm{L}$ & $<50$ \\
\hline ALT & 24 & $\mathrm{U} / \mathrm{L}$ & $<50$ \\
\hline Sodium & 142.0 & $\mathrm{mEq} / \mathrm{dl}$ & $136.00-146.00$ \\
\hline Potassium & 4.20 & $\mathrm{mEq} / \mathrm{dl}$ & $3.50-5.10$ \\
\hline Calcium & 9.60 & $\mathrm{mg} / \mathrm{dl}$ & $8.80-10.60$ \\
\hline Phosphorus & 3.00 & $\mathrm{mg} / \mathrm{dl}$ & $2.40-4.40$ \\
\hline Bilirubin total & 1.00 & $\mathrm{mg} / \mathrm{dl}$ & $0.30-1.20$ \\
\hline Bilirubin Direct & 0.20 & $\mathrm{mg} / \mathrm{dl}$ & $<0.20$ \\
\hline Bilirubin Indirect & 0.80 & $\mathrm{mg} / \mathrm{dl}$ & $<1.10$ \\
\hline
\end{tabular}

On further medical history, patient admitted that several other members in his neighborhood have developed similar painful leg edema recently. During the epidemiological investigation, it was found that all these families were using mustard oil for cooking, which had been extracted from same local oil extraction machine. The mustard oil samples that were being used for cooking by the affected families tested positive for Argemone oil contamination. The presence of Argemone oil contamination was confirmed using nitric acid, cupric acid and ferric chloride test.

Our index case was managed with bed rest with leg elevation and a protein rich diet. Supplements of calcium, antioxidants like vitamin $\mathrm{C}$ and $\mathrm{E}$, thiamine and other B vitamins were given. To relieve oedema patient was started on $20 \mathrm{mg}$ furosemide OD. The oedema resolved in a week and the patient was discharged and is doing fine now.

\section{DISCUSSION}

Epidemic dropsy results from intoxication with argemone oil resulting from its willful adulteration with mustard oil, which is possible by virtue of their similar color (Mukerjee et al., 1941). In the most recent Indian epidemic in 1998, the first case was reported on Aug. 5, 1998 and the epidemic lasted for seven weeks. 2178 cases 
were reported out of which $66(3.2 \%)$ died. This was possibly the largest epidemic in India. The 'Food Safety and Standards of India' (FSSI) have laid down norms for marketing and sale of refined edible vegetable oils in India. According to FSSI, mustard oil for sale must be free of Argemone oil and selling mustard oil contaminated with Argemone oil is liable to be punished by law. These legislative measures have resulted in a change in the epidemiology of the disease. Epidemic dropsy now affects families involved in cultivating, harvesting, and consuming mustard oil that possibly get contaminated with Argemone oil during the harvesting of mustard.

Mukerjee et al. (1941) had isolated a toxic substance from argemone seeds which was later identified as sanguinarine by Sarkar and Rahman, 1945. Argemone seeds contain 2 physiologically active alkaloids; dihydrosanguinarine $(\sim 87 \%)$ and sanguinarine ( 5\%) Sarkar (1948). The fact that argemone oil is responsible for epidemic dropsy has been established by several human feeding trials with argemone oil and argemone adulterated mustard oil (Chopra et al., 1939). These alkaloids have a direct toxic effect on cells. Possible mechanisms are inhibition of Na-K ATPase activity, reduction of ATP production due to reduced glycogen levels, raised Interleukins 1 and 6, elevated TNF- $\alpha$ level, and an increased production of reactive oxygen and nitrogen species which lead to DNA damage and apoptosis (Das et al., 2005). All these mechanisms cause endothelial damage, increased capillary permeability, leakage of protein rich fluid into the interstitial spaces, and vascular damage (Babu et al., 2010).

Review of literature suggests that pitting edema is the main clinical feature in patients with epidemic dropsy, and this finding was corroborated by the results of our study. Other cutaneous findings such as erythema and skin tenderness are the features which were variably reported in previous studies $(35-82 \%$ and $22-88 \%$, respectively) (Tandon et al., 1975) (Gomber et al., 1994) (Singh et al., 2000) (Singh et al., 1998). Other skin changes such as widespread telengiectasis, erythrocyanosis, mottling and blanching were not seen in our case. Our patient didn't developed any cardiological or neurological complication. Anemia is a common feature of epidemic dropsy was seen in our case too (Rangan and Barceloux, 2009).

Withdrawal of the offending agent - the contaminated mustard oil - is the cornerstone of management, being vital to limit the progression of symptoms. A review of the literature based on animal experiments in rats has elaborated upon the use of a high protein diet and vitamin supplementation to replenish the depleted antioxidant levels, which are mainly riboflavin, tocopherol and retinol. We followed the aforementioned recommendations for our patient along with diuretic to relieve edema.

\section{CONCLUSION}

Although epidemic dropsy still exists in India, its mode of presentation has changed from an epidemic to a sporadic pattern. This poisoning should be suspected in patients presenting with edema, erythema, tenderness of the limbs, and a collection of these symptoms within farmer families. Epidemic dropsy can be confirmed by a laboratory exam of contamination of mustard oil with Argemone oil. Withdrawal of the contaminated cooking oil is the most important initial step. Bed rest with leg elevation and a protein-rich diet are useful. Supplements of calcium, antioxidants (vitamin $\mathrm{C}$ and E), and thiamine and other B vitamins are commonly used. Diuretics are used universally but caution must be exercised not to deplete the intravascular volume unless features of frank congestive cardiac failure are present, as oedema is mainly due to increased capillary permeability. Effective strategies to eradicate this poisoning involve public education, mandatory quality inspections, and detection of possible contaminations.

\section{REFERENCES}

Babu C.K., Ansari K.M., Mehrotra S., Patel S., Dikshit M. and Das M., 2010. Activation of inflammatory response and apoptosis of polymorphonuclear leukocytes in patients with argemone oil poisoning. Chem. Biol. Interact, 183(1):154-64.

Chopra R.N., Pasricha C.L., Goyal R.K., Lal S. and Sen A.K., 1939. The experimental production of syndrome of epidemic dropsy in man. Indian Med. Gaz., 74: 143.

Das M. and Khanna S.K., 1997. Clinico epidemiological and safety evaluation studies on argemone oil: CRC. Crit Rev. Toxicol., 27: 273-97.

Das M., Babu C.K., Khanna S.K. and Srivastava L.M., 2005. Oxidative damage of plasma proteins and lipids in epidemic dropsy patients: Alterations in antioxidant status. Biochim Biophys Acta., 1722:209-17.

Das M. and Khanna S.K., 1998. Epidemic Dropsy. The National Med. J. India, 11: 207-208. 
Das M. and Khanna S.K., 1998. Epidemic Dropsy. Natl. Med. J. India, 11(5):207-8.

Gupta R.K., 2009. Food processing, food adulteration, food additives, preservatives, food toxicants and food fortification. In: Bhalawar R., Gupta R., Kunte R., Tilak R., Vaidya R., editors. Textbook of Public Health and Community Medicine. Pune: Department of Community Medicine, Armed Forces Medical College, pp.791-797.

Gomber S., Daral T.S., Sharma P.P. and Faridi M.M., 1994. Epidemic dropsy in Trans Yamuma areas of Delhi and U.P. Indian Pediatr., 31(6):671-4.

Kumar A., Husain F., Das M. and Khanna S.K., 1992. An out-break of epidemic dropsy in the Barabanki District of Uttar Pradesh, India: a limited trial for the scope of antioxidants in the management of symptoms. Biomed Environ Sci., 5:251-256.

Mukerjee S.P., Lal R.B. and Mathur K.B.L., 1941. Investigation into the epidemiology of epidemic dropsy. XII Isolation of active substances from toxic oils. Indian J. Med. Res., 29: 361.

Park K., 2009. Park's Textbook of Preventive and Social Medicine. Jabalpur: M/s Banarsidas Bhanot. Nutrition and health: food toxicants: epidemic dropsy; p. 570.

Rathore M.K., 1982. Ocular manifestations of epidemic dropsy. Indian J. Ophthalmol., 30: 307-309.

Rangan C. and Barceloux D.G., 2009. Food Contamination. Disease-a-Month, 55:263-91.

Sarkar S.N. and Rahman M.B., 1945. A chemical method for the estimation of alkaloid present in argemone and mustard oils. Curr. Sci., 14: 196.
Sarkar S.N., 1948. Isolation from argemone oil of dihydrosanguinarine and sanguinarine: toxicity of sanguinarine. Nature (London), 162: 265-266.

Sarkar S.L., 1926. Katakar oil poisoning. Indian Med. Gaz., 61: 62-63.

Sachdev H.P.S., Sachdev M.S., Verma L., Sood N.N. and Moonis M., 1989. Electrophysiological studies of the eye, peripheral nerve and muscles in epidemic dropsy. J. Trop. Med. Hyg., 92: 412415.

Smith D.B., 1937. Investigations into the epidemiology of epidemic dropsy. Part I. Indian J. Med. Res., 26: 163-176.

Singh R., Faridi M.M., Singh K., Siddiqui R., Bhatt N. and Karna S., 1999. Epidemic dropsy in the eastern region of Nepal. J. Trop. Pediatr., 45:813.

Singh K., Singh M.J. and Das J.C., 2006. Visual field defects in epidemic dropsy. Clin. Toxicol (Phila) 44:159-163.

Singh N.P., Anuradha S., Dhanwal D.K., Singh K., Prakash A., Madan K. and Agarwal S.K., 2000. Epidemic dropsy--a clinical study of the Delhi outbreak. J. Assoc. Physicians India, 48(9):87780 .

Singh R., Faridi M.M., Singh K., Siddiqui R., Bhatt N. and Karna S., 1998. Epidemic dropsy in the eastern region of Nepal. J. Trop. Pediatr., 45(1):8-13.

Tandon P.K., Singh S., Arora R.R., Lal P. and Tandon B.N., 1975. Epidemic dropsy in New Delhi. Am. J. Clin. Nutr., 28:883-7. 